\title{
Heavy Rainfall and Landslide Event in January 1831 at the Pedregoso Mountains (Cabeza Del Buey, SW Spain)
}

\author{
Juan Pedro García-Garrido ${ }^{1, *(D)}$, María Cruz Gallego ${ }^{1}$, Teodoro Palacios ${ }^{2} \oplus$, Ricardo M. Trigo ${ }^{3,4}$ \\ and José Manuel Vaquero ${ }^{5}$ (D) \\ 1 Departamento de Física, Universidad de Extremadura, 06006 Badajoz, Spain; maricruz@unex.es \\ 2 Departamento de Biología Vegetal, Ecología y Ciencias de la Tierra, Universidad de Extremadura, \\ Avda. de Elvas s/n, 06006 Badajoz, Spain; palacios.teodoro@gmail.com \\ 3 Instituto Dom Luiz (IDL), Faculdade de Ciências, Universidade de Lisboa, Campo Grande, 1749-016 Lisbon, \\ Portugal; rmtrigo@fc.ul.pt \\ 4 Departamento de Meteorologia, Instituto de Geociências, Universidade Federal do Rio de Janeiro, \\ Rio de Janeiro 91501-970, Brazil \\ 5 Departamento de Física, Universidad de Extremadura, 06800 Mérida, Spain; jvaquero@unex.es \\ * Correspondence: jgarciagar@unex.es
}

Received: 22 April 2020; Accepted: 18 May 2020; Published: 23 May 2020

\begin{abstract}
In this work, a landslide event that took place on January 1831 at the Pedregoso Mountains, Cabeza del Buey, SW Spain, is described. This landslide had not been documented to date and was only described in the local press. This event involved an estimated amount of dislodged material in the order of $10^{4} \mathrm{~m}^{3}$. The amount of meteorological data is very scarce as the event occurred before the setting up of the national meteorological service in Spain. However, data from the relatively near location of SW Iberia suggest that the landslide was preceded by a prolonged period of unusually high precipitation totals and that this intense wet period is compatible with the large-scale atmospheric configuration in the winter of 1829-1830. In fact, the North Atlantic Oscillation (NAO) index for that winter achieved one of the most negative values observed in the bicentennial period spanning 1821 to 2019. This multidisciplinary work represents the first attempt to report and describe the main triggering mechanism for an historical landslide in the Extremadura region that is similar to other great historical landslides which have already been documented for other locations in Spain.
\end{abstract}

Keywords: landslides; floods; extreme precipitation; NAO; Iberian Peninsula; natural hazard

\section{Introduction}

Landslides are a geological phenomenon that consists of the movement of a mass of soil, rock and debris down the mountain slopes [1,2]. These events are usually associated with the loss of human lives and with important economic damages [3]. Landslides can be described as physical systems that evolve in time through different stages [4]. The speed of the landslide and the volume they displace depend on intrinsic and extrinsic triggering factors [5]. The intrinsic factors include the geology of the area and the geometry of the mountain slope. The most important extrinsic factor is rainfall $[3,6]$. Several European regions have developed significant efforts to gather and characterize all information on historical geomorphological hazards (floods and landslides), often based on documental sources (e.g., [6,7]). For example, based on many thousands of newspaper articles, it was possible to gather a comprehensive catalogue on past landslides (and floods) that impinged human consequences in Portugal since 1865 [7]. However, not even these assessments are capable of describing all events before the generalized use of meteorological stations or newspapers, only the largest ones, such as 
the event described here. Thus, despite the efforts to better assess the climate of the SW during the first half of the 19th century, there are large gaps to be filled. This work aims to study the landslide event of January 1831 at the Pedregoso Mountains, Southwest Spain, for a better understanding of the occurrence rate of this kind of natural disaster and the triggering factors in the region, because there are no landslides like this one in the literature on this subject.

The city of Cabeza del Buey is located in the southwest of Spain $\left(38^{\circ} 43^{\prime} \mathrm{N}, 5^{\circ} 13^{\prime} \mathrm{W}, 531 \mathrm{masl}\right)$ in the region of Extremadura (Figure 1). Its landscape is dominated by the Pedregoso Mountains (foothills of Sierra Morena), being situated in the north slope of these mountains. The Pedregoso Mountains have several peaks with elevations higher than 800 masl. Its climate is classified as Köppen type Csa, mild with hot and dry summer [8]. In addition, it is possible to indicate that the SW of the Iberian Peninsula (IP) has equal climatic characteristics, with a climate classified as Köppen type Csa in almost all of its territory [8]. Although other landslide events have been reported in Spain [3,9-13], none of them were reported in Extremadura region, where Cabeza del Buey is located. Thus, it is important to document this large event because of the absence of similar records in the region. In fact, it is worthy of mention that there are numerous historical cases of different natural hazards in the region of Extremadura (floods, earthquakes, etc.) except for landslides [14,15], so this study has important repercussions for the management of the Pedregoso Mountains and other areas of SW Iberia with similar geological or meteorological conditions.

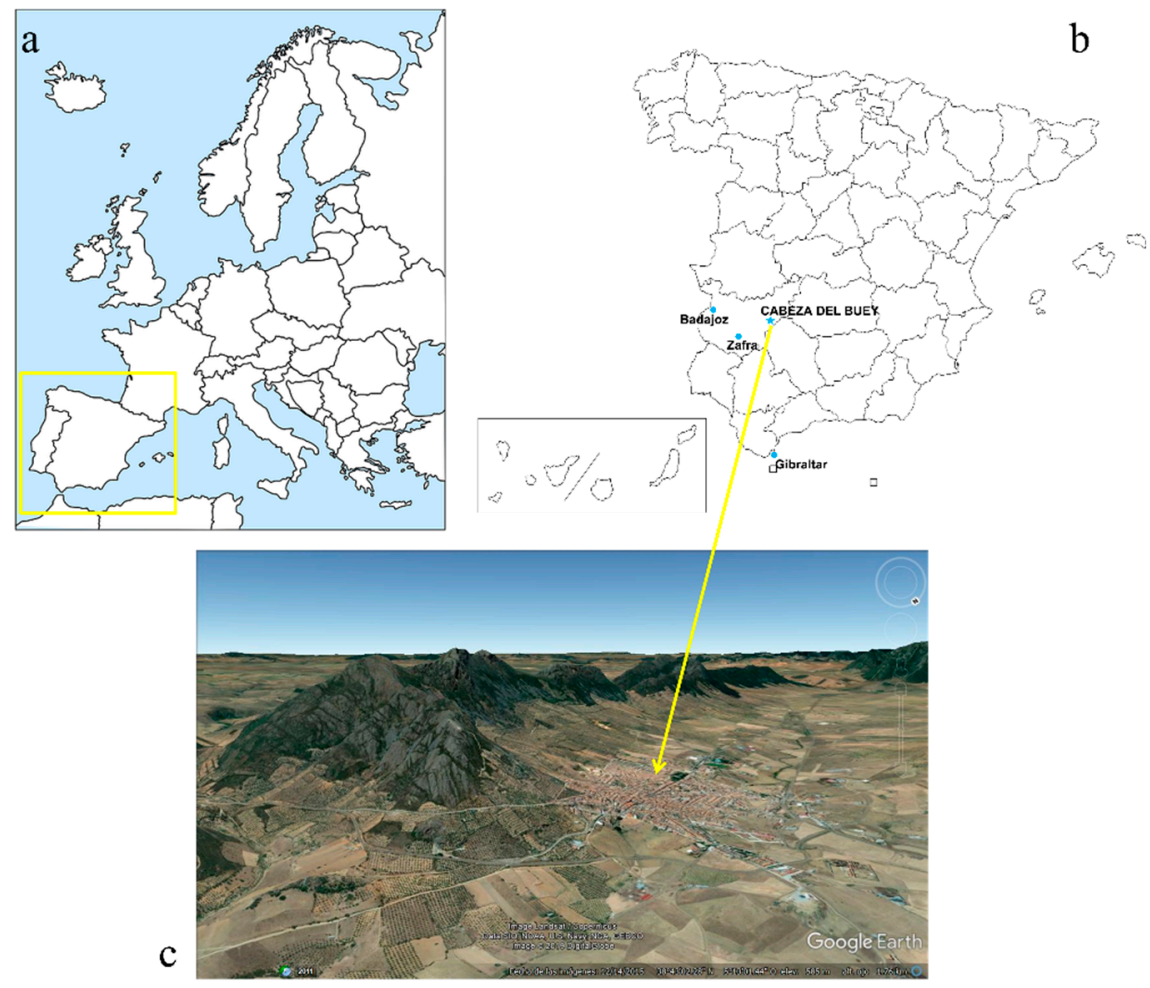

Figure 1. (a) Location of Spain; (b) location map of the study area (Cabeza del Buey) as well as other places where rainfall data were obtained (Badajoz, Zafra and Gibraltar); (c) topographic view of Cabeza del Buey.

\section{Geological Setting}

The study area is represented by three lithological units (Figure 2): The older Ediacaran unit includes alternated layers of greywacke and shale, which are impermeable rocks that upon weathering give rise to clay soils. Overlaying, in angular and erosive unconformity, is located the Lower Ordovician Armorican Quartzite, which is mainly composed of orthoquartzite, resistant to chemical weathering and which build the most important topographic reliefs. Orthoquartzite is brittle, highly fractured, 
permeable and usually forms aquifers whose confining unit is the contact with the impermeable Ediacaran rocks. The more recent Quaternary unit includes unconsolidated colluvium, caused by the gravity-induced build-up of blocks from the fractured quartzites of the Ordovician, that accumulate in the areas of maximum slope [16,17]. These materials are very unstable and have a high permeability.
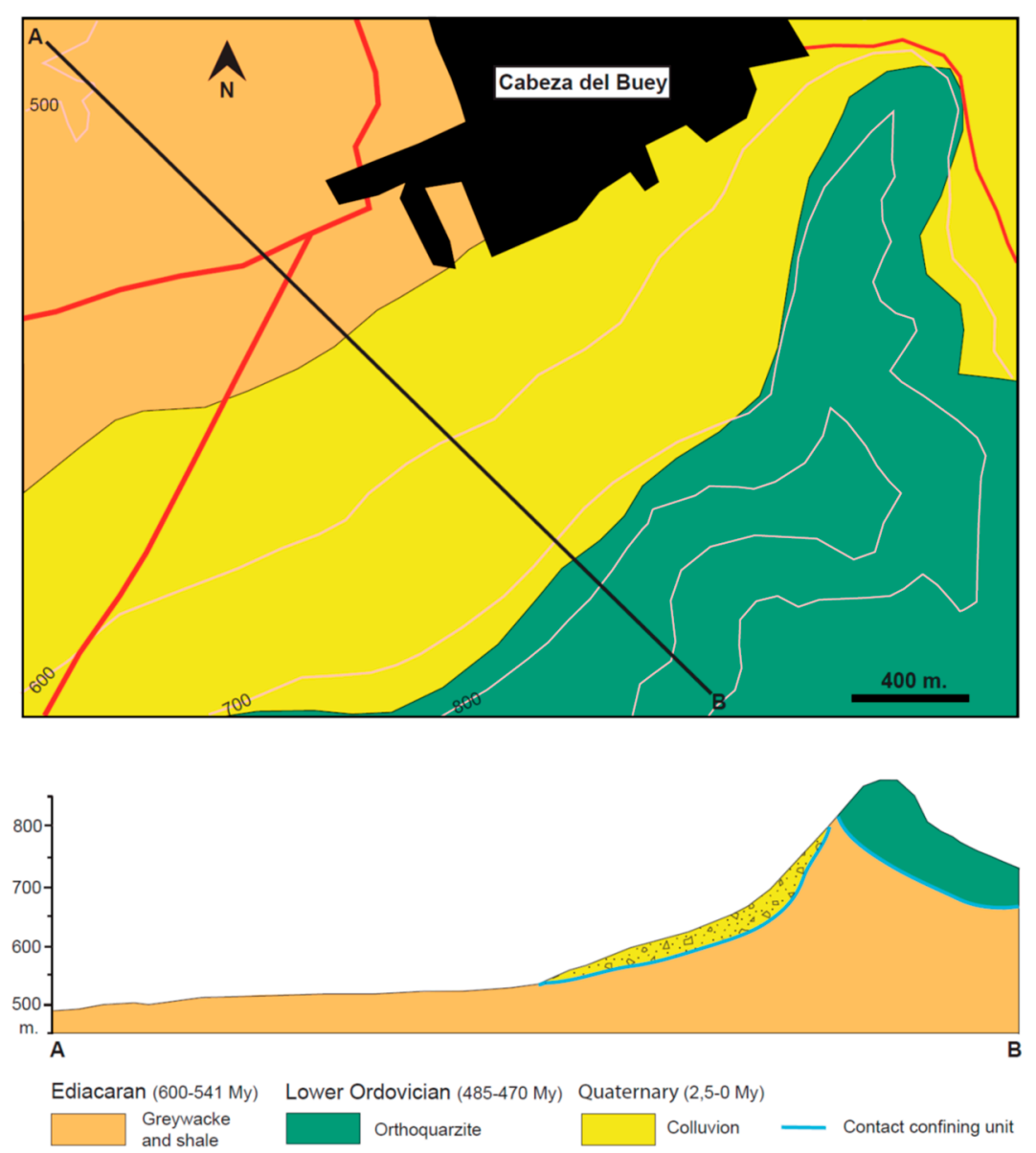

Figure 2. Geological map of Cabeza del Buey and Pedregoso Mountains and geological cross-section of the north slope of the Mountain Range.

When significant precipitation occurs, large amounts of water infiltrate the colluvium causing a great recharge of the aquifer and into the confining unit (contact with the weathered and impermeable clay materials of the Ediacaran, Figure 2). This increases the plasticity of the clays favoring gravity slippage in the areas of higher slope. Another possible effect, given the great permeability of the colluvium, is the erosion of the clay materials at the contact surface, facilitating the collapse of the colluvium. Both effects would cause gravity slippage of the unconsolidated colluvium in times of heavy rainfall, as could be the case with the event described.

Given the great extension of this landslide, it is interesting and important to make a rough evaluation of the total volume of materials dislodged. Using data from "Diario de Badajoz", presented in Section 3.2, it was considered that the fissure had a length of $1250 \mathrm{~m}$ and was $50 \mathrm{~cm}$ wide. Finally, thickness is a difficult parameter to be estimated, but in this case, it can be approximated due to the fact that mountain slope deposits do not have great thickness values. Therefore, it was estimated at $20 \mathrm{~m}$, a normal value for this kind of material. Thus, the resulting calculation was of $12,500 \mathrm{~m}^{3}$, an order of magnitude of $10^{4} \mathrm{~m}^{3}$ of mass involved in this event $[16,17]$. 


\section{Rainfall Data}

When studying the past climate, it is often difficult to access data that corresponds precisely to the researched period and to the exact area. For that reason, it is necessary to evaluate the availability of different sources of information like indirect references (or proxy data) and man-made documentary sources. Some examples of indirect sources in Western Iberia are the study of tree rings [18], fossil pollen [19] or lake sediments [20] that allow a relatively comprehensive climate reconstruction for the last millennium [20,21]. As for documentary data, some examples are annals, chronicles, private correspondence, newspapers, paintings or photographs, early instrumental observations and ship logbooks, among others, as reviewed by [22,23]. In this context it is important to stress several works with these documentary sources for SW Iberia published in the last decade [24-28].

The studied event took place in 1831, therefore, there was not much information nor exhaustive data available about precipitation from this area. In this year, there were no proper national meteorological services in Spain yet (nor in many countries of Europe). National institutions in Iberia did not coordinate well the activities of scientists and this led to the poor development of the meteorological observations. This period was also characterized by several political conflicts and many wars in Spain that lasted until the middle of the twentieth century [27]. Nevertheless, despite this unfavorable context, it was possible to obtain important data from near locations shown in Figure 1. Two types of data are used throughout this article: meteorological data and data from reports and newspaper articles. They were obtained from a wide range of sources, including libraries, online repositories and contemporary documents.

\subsection{Meteorological Data}

Meteorological data from Cabeza del Buey could not be found. However, there were contemporary registers from Badajoz and from Gibraltar that were available and will be used in this article.

Badajoz, located to the west of Cabeza del Buey, was already a relatively large city at the time in this province. Fortunately, there are some available observations [27] consisting of three-times per day qualitative indications about the weather, from 1830 to 1833 . The rainy days were counted, and then the counts were grouped in quarterly intervals (removing those with lost data), and results can be observed in Figure 3a. The quarter Nov 1830-Dec 1830-Jan 1831 stands out for being the one with the greatest amount of rainy days and the difference in amount of rainy days between this period and the remaining quarters is significant, presenting roughly double the number of rainy days than the same quarter of the following year.

Gibraltar records [29] were formed by a monthly number of rainy days register. The period of data available was from 1821 to 1832 . All data was grouped in quarterly intervals and can be observed in Figure 3b. This figure clearly shows that the second greatest peak is the quarter November 1830-December 1830-January 1831, corresponding to the period of the studied landslide. There is only one quarter with a greater number of rainfall days in Gibraltar, corresponding to November 1829-December 1829-January 1830, with a few more registers. With such a wet previous winter, it is likely that the ground moisture was already much higher than the average, and that ground moisture in the studied winter was closer to saturation and thus more prone to the occurrence of landslides. Both of these quarters surpass the intense precipitation seasonal cycle, represented by the mean plus one standard deviation dotted curve, a threshold value that is often used to easily evaluate how uncommon these winter months were. In general terms, the lack of major mountains between the Atlantic coast and the study area implies that SW Iberia has the same climate type in the Köppen Classification. In particular, the link between the most important large-scale pattern of atmospheric circulation (NAO) and local rainfall in Gibraltar and in Cabeza del Buey is quite similar, especially in winter. That makes Gibraltar's data very important, despite its distance to the study area.

As shown, Badajoz and Gibraltar data are consistent with the fact that the rain event of December 1830-January 1831 was relevant and anomalous, having many more rainfall days than what is usually recorded for these stations. It is well known that winter months characterized with precipitation 
amounts and frequency of wet days above the average in western Iberia are preferably associated to the negative phase of the North Atlantic Oscillation (NAO) [30]. To assess this issue more in depth, the NAO index, shown in Figure 3c, will be examined in Section 4 of this article.
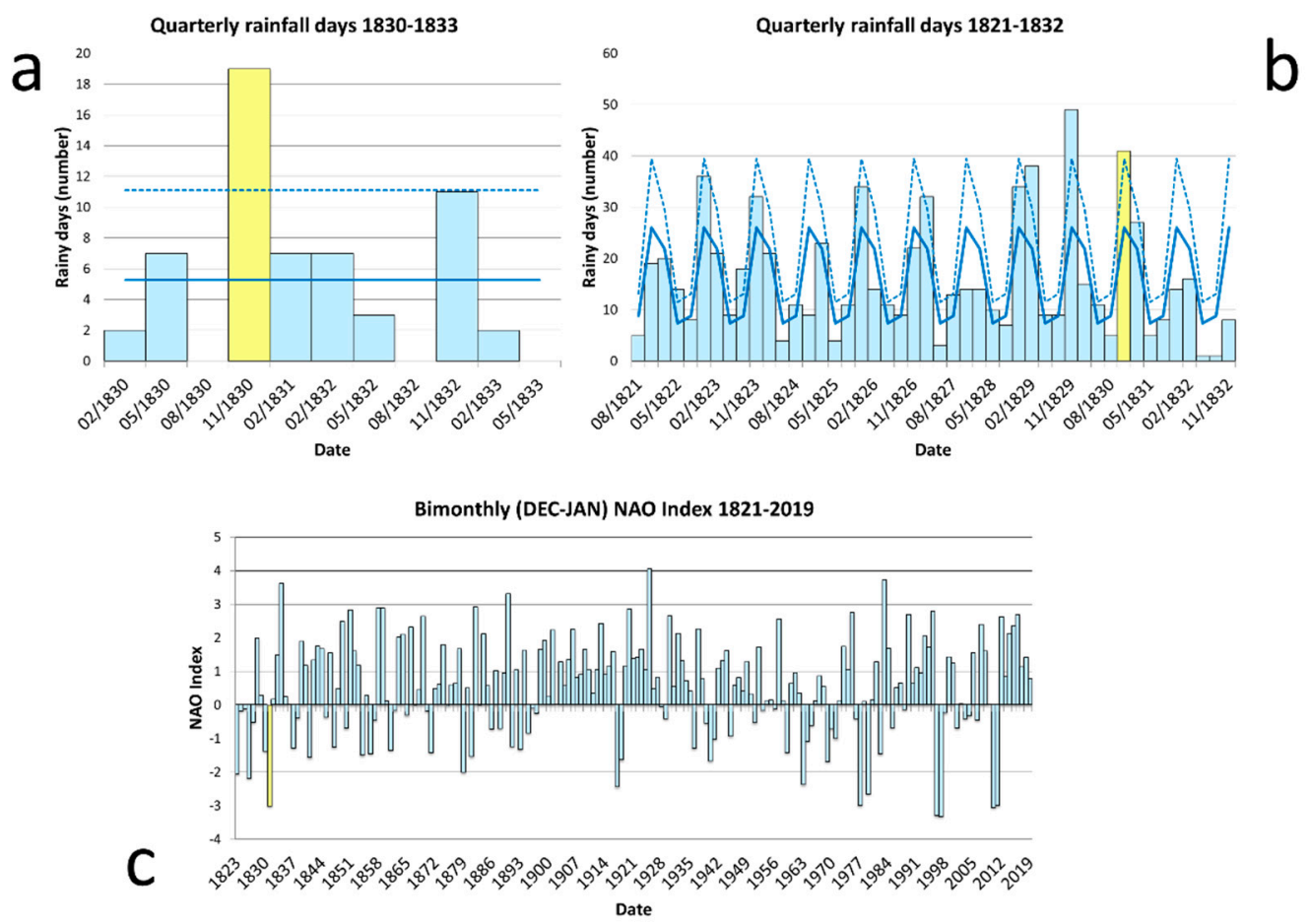

Figure 3. (a) Quarterly rainfall days 1830-1833 in Badajoz; (b) quarterly rainfall days 1821-1832 in Gibraltar. The dotted line represents mean + standard deviation of the values, and the solid line below, the mean; (c) bimonthly (DEC-JAN) North Atlantic Oscillation (NAO) index 1821-2019. Values observed during the reported event are highlighted in yellow.

\subsection{Reports and Newspapers}

In this case, it was possible to access a newspaper from Badajoz called "Diario de Badajoz", from the 19th century [31], as well as the description of weather observations made in the Duchy of Feria in the period 1750-1840 [32].

The article of 4 February 1831, from "Diario de Badajoz" (Figure 4) described an outstanding rainy event, followed by a horrific noise and the appearance of a crevice at the north slope of the mountain. In the southern slope of the mountains some strange movements were equally perceived:

"[...] It was about half past twelve on 21 January 1831 when a terrible noise, lasting two minutes, was heard; and an excessive amount of rain was falling at the same time. After that, an E-W oriented crevice appeared in the north face of the mountain slope, where the village is built. The fissure, $1.25 \mathrm{~km}$ long, smashed stones and walls of the surrounding farming lands. This crevice was $20-56 \mathrm{~cm}$ wide and has remained unchanged to date.

In the southern slope of the same mountain a similar spectacular noise was heard at 9 in the morning. Those herdsmen, present at the time, saw the shaking of the whole mountain range in several directions, as if it was going to collapse; they also saw huge cracking stones, and other phenomena $[\ldots] . "$

Weekly reports about weather in the Duchy of Feria were carried out in its capital, Zafra [28]. Here, a local accountant regularly informed the main accountant of Madrid, where the Duke of Feria lived, about the most important events happened in his duchy. Among all this information, a large number of consistent notes including meteorological situations or related events (such as crops 
developing or prices) were found and have been used to infer weather conditions. In fact, [32,33] reconstructed monthly precipitation and temperature indices for the period 1750-1840 based on these documentary sources.
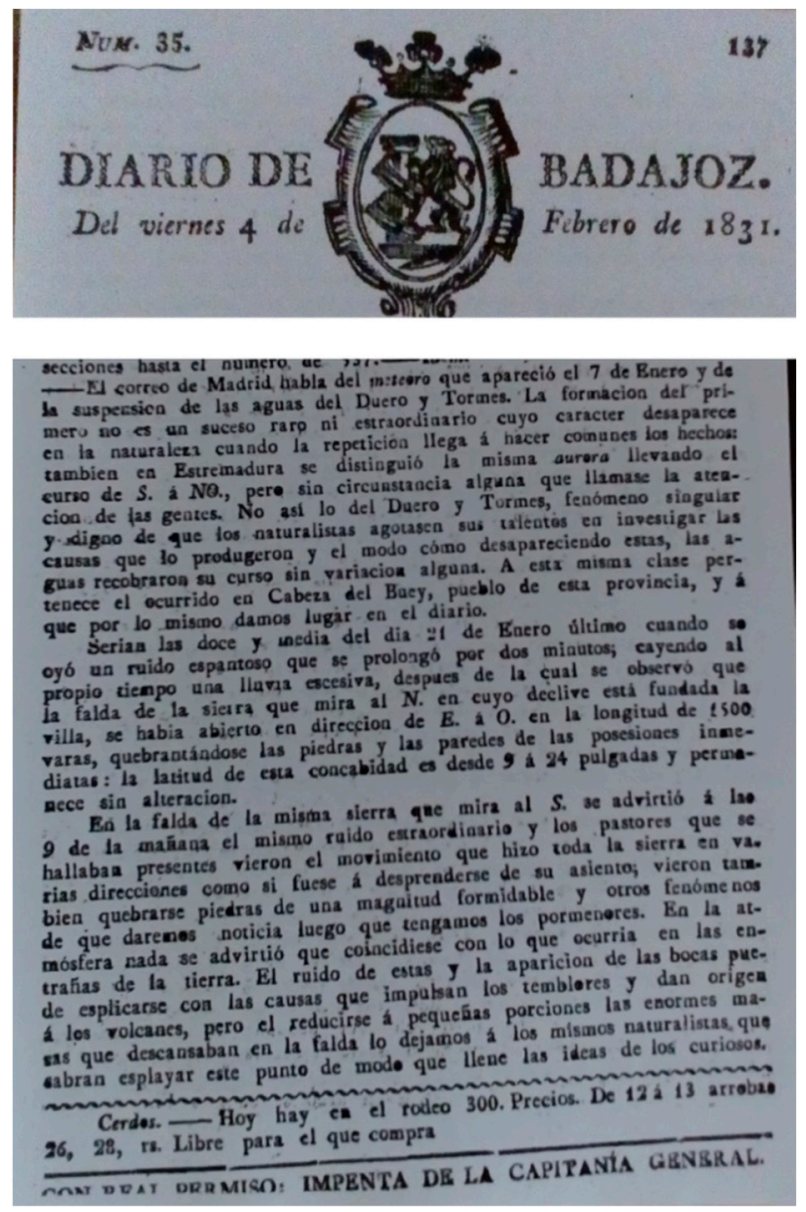

Figure 4. Article of 4 February 1831, from “Diario de Badajoz" [31].

There are two dates in the weekly reports very close to the landslide event date in Cabeza del Buey. First, on 17 January, the register says that there were continuous rainy days. The second note is from 24 January, three days after the landslide had happened. This note describes a terrible socioeconomic and human situation, with lots of laborers having to be accommodated in wealthy people's houses, because they could not work in the fields, completely flooded after two consecutive months of abundant rain.

"Continuously rainy weather, the roads are impassable". [Original text: "El tiempo de continuas lluvias, tal que están intransitables los caminos".] (17 January, 1831)

"The abundant and continuous rain from the last two months has made field works absolutely impossible for the conclusion of the sowing and for the olive harvest, which employs the most part of the infinite laborers that live in this village. Needy and hungry, as their families, they surprisingly met in groups at the houses of the property owners, being required the judicial authority intervention to calm the situation and to agree on how should the really needy people be helped. [ ... ] it was impossible to take such a great amount of needy people in the wealthy people houses. [ ... ] The weather is still changeable. There have been infinite misfortune events of drowned people at rivers and streams near this location, as well as herd, that were going to be sold in different points of the province. Many drivers have been 
stopped for five days". [Original text: "Las abundantes continuas lluvias de dos meses a el presente han imposibilitado del todo los trabajos de campo, así para la conclusión de la sementera, como el de cogida de aceituna, cuya cosecha buena ocupaba infinitos jornaleros de que se compone el mayor número de vecinos de esta villa, necesitados y hambrientos como sus infelices familias, se reunieron en grupos abocándose y sorprendiendo las casas de varios hacendados, cuya ocurrencia y disgustos obligó a la autoridad judicial a poner remedio y acordar como habían de ser socorridos los verdaderamente necesitados. [ ... ] no siendo posible colocar el gran número de necesitados en las casas de los pudientes [ ... ] El tiempo sigue vario: Son infinitas las desgracias de personas ahogadas en las riveras o arroyos de estas inmediaciones, y también ganados de cerda, gordos que pasaban para su venta a distintos puntos de la provincia. Los conductores de valija han estado detenidos cinco días."] (24 January, 1831)

\section{NAO Index and Synoptic Conditions}

The most important large-scale mode of climate variability in south-western Europe is the North Atlantic Oscillation that consists of a north-south dipolar pattern in sea-level pressure, with one center placed in Iceland, and the other one near the Azores islands [30]. The positive phase of the NAO indicates stronger-than-usual low-pressure centers affecting the high latitudes of the North Atlantic, while high pressure centers dominate the area spanning the area between the Azores and the Iberian Peninsula (IP). During the negative phase of the NAO, the situation is the opposite. NAO is one of the most broadly studied climatic indices [34,35] and has been found to be strongly related to precipitation in Western Europe and the Mediterranean basin. This is linked to changes in the activity and orientation of the North Atlantic storm trajectories and precipitation [30]. It is important to stress that previous long-term assessments on landslide frequency close to Lisbon (Portugal) confirm that these geomorphological hazards occur more frequently (and are deeper on average) during winter months characterized by strong negative NAO values [36,37].

Here, we used the NAO index defined by [38] that is calculated as the difference of normalized sea level pressure observed between Gibraltar and Reykjavik, Iceland. Data include monthly values from 1821 to 2019.

Reference [39] found that the winter NAO index affected mainly the intense winter rainfall events, whereas light and moderate rainfall were less affected by this index. In general, when the NAO index is in a positive phase, the weather in Europe is warm, with abundant rain in the north of the continent, and less precipitation throughout Southern Europe [40,41]. In Iberia, [39] found the best correlations with the winter NAO in the west, southwest and in the interior, while on the Mediterranean coast and in the north of Iberia, this correlation was worse.

Winter bimonthly mean values representative of December (year $n-1$ ) and January (year $n$ ) of the NAO index are represented in Figure 3c. It is important to notice that the period of December 1830-January 1831 presents one of the most negative NAO index values for the entire period, with the few similar negative periods being observed only closer to the late 20th century. This strong NAO index value (relative to December 1830 and January 1831) confirms that the large-scale atmospheric circulation at the time was likely dominated by the passage of frequent low-pressure systems, i.e., storm tracks [30], with relatively intense precipitation events associated.

In order to characterize the atmospheric circulation during the relevant months, the Sea Level Pressure (SLP) reconstructed dataset developed by [42] was used. They applied a principal component regression analysis to early instrumental series and proxy data to reconstruct this index back to 1659 with monthly values, and to 1500 with seasonal values. This dataset has been applied successfully in many studies of climate reconstruction $[43,44]$. Figure 5 (left) shows the monthly average SLP pattern between November 1830 and February 1831, including January 1831, when the landslide of Cabeza del Buey took place. It is also possible to visualize the monthly anomalies for this pattern (Figure 5, right). 
a

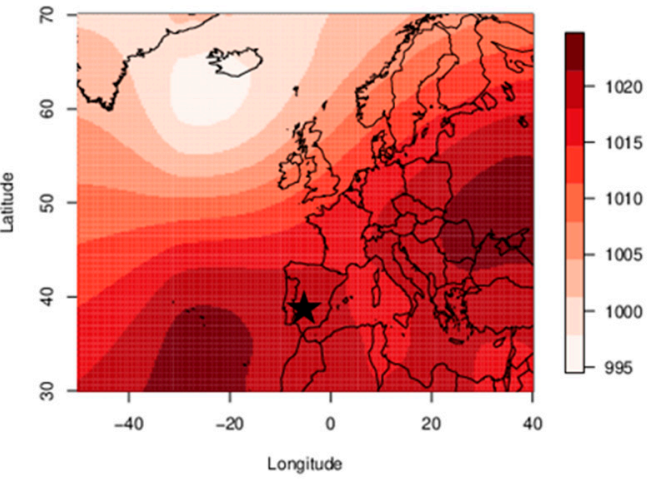

b

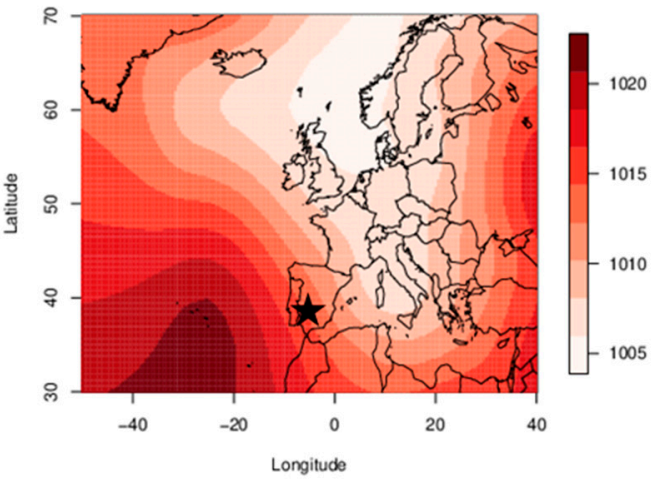

C

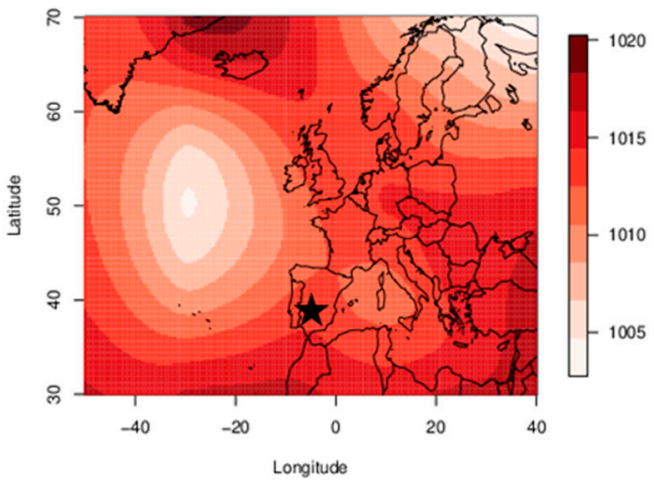

d

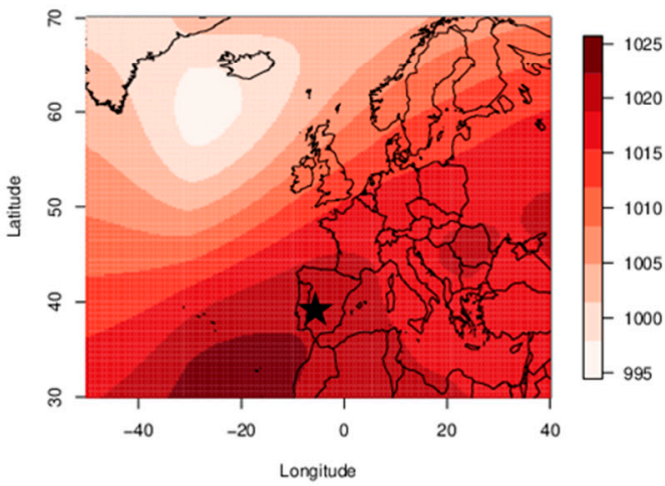

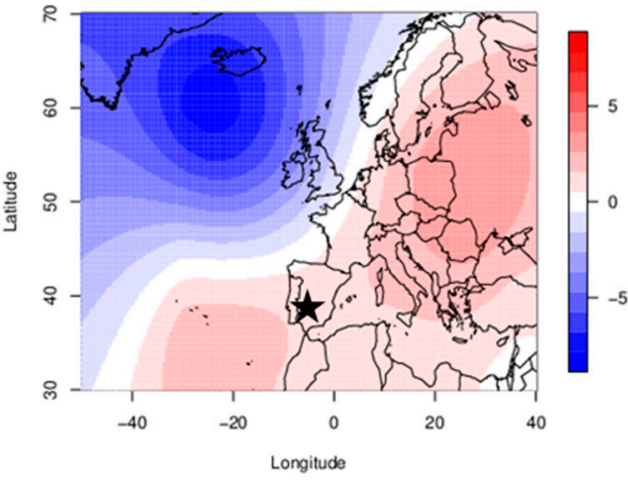
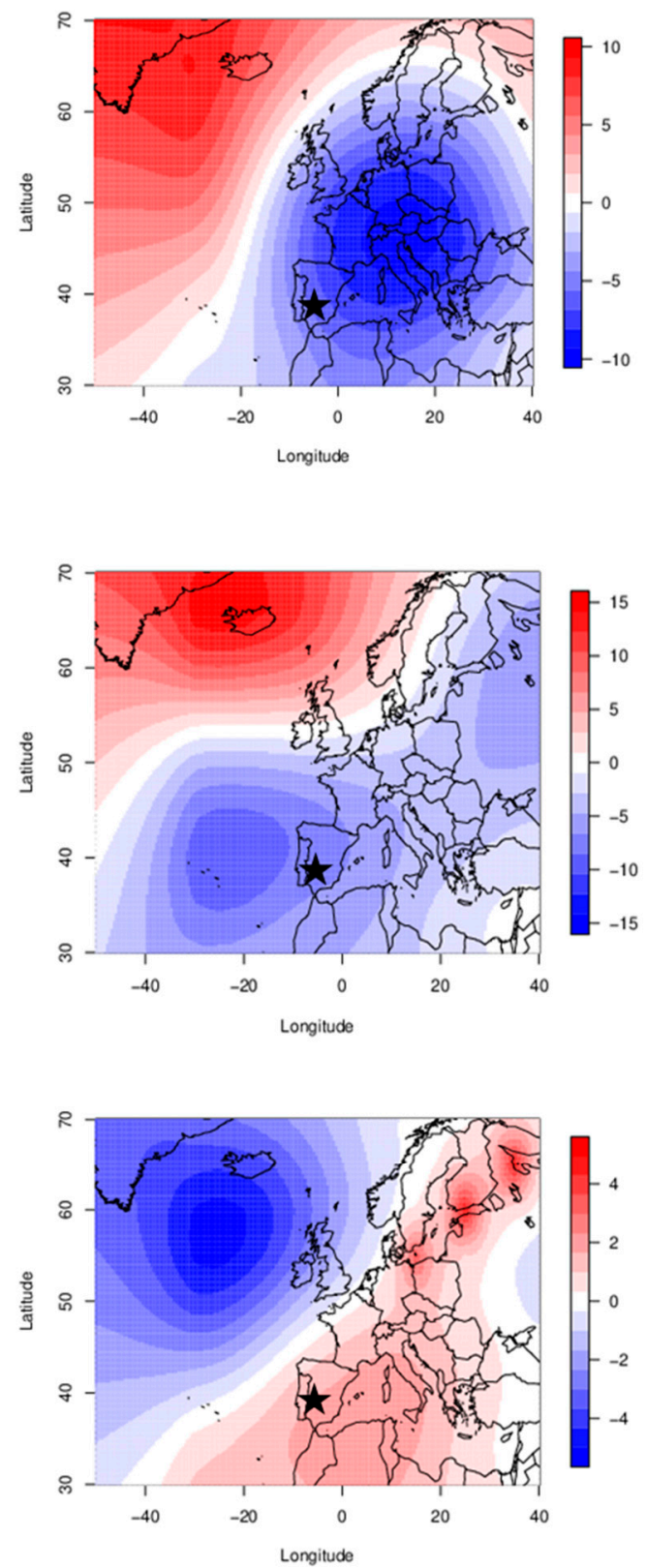

Figure 5. Monthly average of Sea Level Pressure (SLP) values, on the left, and monthly SLP anomalies, on the right, for (a) November 1830; (b) December 1830; (c) January 1831; (d) February 1831. The location of the studied region is clearly marked with a star in all maps. 
It is remarkable in Figure 5 that, even at monthly scale, it is possible to observe the presence of a low-pressure center near the IP, over the Atlantic Ocean, during December 1830 and January 1831. This contrasts with the mostly high-pressure influence that was registered throughout the previous and subsequent months of November and February, respectively. Also, the anomaly maps show important negative anomalies in Iberia during the aforementioned months. SW of IP in general (and Extremadura region in particular) is mostly affected by Atlantic depressions, producing the most important rain events of these areas. Sometimes, these low-pressure centers that affect the IP are associated with structures called Atmospheric Rivers, which enhances the amount of moisture and lead to greater amounts of precipitable water [45].

\section{Discussion}

Here is presented a description of the landslide event at the Pedregoso Mountains close to Cabeza del Buey, SW Spain, in January 1831. The geological structure of the studied area is vulnerable to heavy rainfall, as the unconsolidated colluvial deposits, which accumulate in high proportions in the areas of maximum slope, can be removed downhill by the combined action of water and gravity. This is a typical topography in the highlands of Extremadura, appearing more frequently in the province of Cáceres and in the north of the province of Badajoz. It was estimated that the volume of mass dislodge in this event was in the order of $10^{4} \mathrm{~m}^{3}$.

For the evaluation of the meteorological situation that caused the landslide, data available from nearby locations were used. The data were consistent and pointed out the singularity of the situation and confirm the rainy nature of the days and weeks leading to the event. The period of time when the landslide took place was characterized by one of the most negative values of the NAO index observed for the 200-yr period spanning between 1821 and 2019, explaining the appropriate setting to observe much higher-than-usual precipitation levels. Maps based on Sea Level Pressure show an important low-pressure center located in Western Europe, during December 1830 and January 1831, in contrast with the previous and subsequent months and the previous and following winters.

With these results, the conclusion is that the reported event was in fact a landslide triggered by the unfavorable weather during the entire winter season, with continuous rain, that affected the terrain stability and caused several misfortunes.

Author Contributions: Data curation, M.C.G. and J.M.V.; formal analysis, J.P.G.-G. and T.P.; investigation, J.P.G.-G., M.C.G., T.P., R.M.T. and J.M.V.; resources, R.M.T.; writing of the original draft, J.P.G.-G. and T.P; writing, reviewing and editing, M.C.G., R.M.T. and J.M.V. All authors have read and agreed to the published version of the manuscript.

Funding: This research was supported by the Economy and Infrastructure Counselling of the Junta of Extremadura through project IB16127 and grant GR15137 (co-financed by the European Regional Development Fund) and by the Ministerio de Ciencia e Innovación of the Spanish Government (CGL2017-87917-P).

Conflicts of Interest: The authors declare no conflict of interest. The funders had no role in the design of the study; in the collection, analyses or interpretation of data, in the writing of the manuscript or in the decision to publish the results.

\section{References}

1. Fowze, J.S.M.; Bergado, D.T.; Soralump, S.; Voottipreux, P.; Dechasakulsom, M. Rain-triggered landslide hazards and mitigation measures in Thailand: From research to practice. Geotext. Geomembr. 2012, 30, 50-64. [CrossRef]

2. Haque, U.; Da Silva, P.F.; Devoli, G.; Pilz, J.; Zhao, B.; Khaloua, A.; Wilopo, W.; Andersen, P.; Lu, P.; Lee, J.; et al. The human cost of global warming: Deadly landslides and their triggers (1995-2014). Sci. Total Environ. 2019, 682, 673-684. [CrossRef] [PubMed]

3. Gutiérrez-Martín, A.; Herrada, M.Á.; Yenes, J.I.; Castedo, R. Development and validation of the terrain stability model for assessing landslide instability during heavy rain infiltration. Nat. Hazards Earth Syst. Sci. 2019, 19, 721-736. [CrossRef] 
4. Hungr, O.; Leroueil, S.; Picarelli, L. The Varnes classification of landslide types, an update. Landslides 2014, 11, 167-194. [CrossRef]

5. Guzzetti, F.; Peruccacci, F.; Rossi, M.; Stark, C.P. Rainfall thresholds for the initiation of landslides in central and southern Europe. Meteorol. Atmos. Phys. 2007, 98, 239-267. [CrossRef]

6. Guzzetti, F.; Tonelli, G. Information system on hydrological and geomorphological catastrophes in Italy (SICI): A tool for managing landslide and flood hazards. Nat. Hazards Earth Syst. Sci. 2004, 4, 213-232. [CrossRef]

7. Zêzere, J.L.; Pereira, S.; Tavares, A.O.; Bateira, C.; Trigo, R.M.; Quaresma, I.; Santos, P.; Santos, M.; Verde, J. DISASTER: A GIS database on hydro-geomorphologic disasters in Portugal. Nat. Hazards 2014, 72, 503-532. [CrossRef]

8. Agencia Estatal de Meteorología; Iberian Climate Atlas; Instituto de Meteorologia de Portugal: Madrid, Spain, 2011.

9. Alfaro, P.; Delgado, J.; García-Tortosa, F.J.; Lenti, L.; López, J.A.; López-Casado, C.; Martino, S. Widespread landslides induced by the Mw 5.1 earthquake of 11 May 2011 in Lorca, SE Spain. Eng. Geol. 2012, 137-138, 40-52. [CrossRef]

10. Costanzo, D.; Rotigliano, E.; Irigaray, C.; Jiménez-Perálvarez, J.; Chacón, J. Factors selection in landslide susceptibility modelling on large scale following the gis matrix method: Application to the river Beiro basin (Spain). Nat. Hazards Earth Syst. Sci. 2012, 12, 327-340. [CrossRef]

11. Corominas, J.; Moya, J. Reconstructing recent landslide activity in relation to rainfall in the Llobregat River basin, Eastern Pyrenees, Spain. Geomorphology 1999, 30, 79-93. [CrossRef]

12. Corominas, J.; Matas, G.; Ruiz-Carulla, R. Quantitative analysis of risk from fragmental rockfalls. Landslides 2019, 16, 5-21. [CrossRef]

13. Remondo, J.; González, A.; Díaz de Terán, J.R.; Cendrero, A.; Fabbri, A.; Chung, C.-J.F. Validation of Landslide Susceptibility Maps; Examples and Applications from a Case Study in Northern Spain. Nat. Hazards 2003, 30, 437-449. [CrossRef]

14. Ceballos-Zúñiga Rodríguez, F.; Gamero Ceballos-Zúñiga, E.; Fresno López, F.E. Análisis integrado de riesgos naturales e inducidos de la Comunidad Autónoma de Extremadura. In Dirección General de Urbanismo; Arquitectura y Ordenación del Territorio de la Junta de Extremadura: Mérida, España, 1990.

15. Trigo, R.M.; Varino, F.; Ramos, A.M.; Valente, M.A.; Zêzere, J.L.; Vaquero, J.M.; Gouveia, C.M.; Russo, A. The record precipitation and flood event in Iberia in December 1876: Description and synoptic analysis. Front. Earth Sci. 2014, 2, 3. [CrossRef]

16. Palacios, T.; Eguíluz, L.; Apalategui, O.; Jensen, S.; Martínez-Torres, L.; Carracedo, M.; Gil Ibarguchi, J.I.; Sarrioiandía, F.; Martí Mus, M. Mapa Geológico de Extremadura a escala 1:350.000; Servicio Editorial de la Universidad del País Vasco (UPV/EHU): Bilbao, Spain, 2013.

17. Valverde Hernández, M.F. Mapa y Memoria Explicativa de la Hoja nr 806 (Cabeza del Buey) del Mapa Geomorfologico de España a escala 1:50 000; IGME: Madrid, Spain, 2005.

18. Kurz-Besson, C.B.; Lousada, J.L.; Gaspar, M.J.; Correia, I.E.; David, T.S.; Soares, P.M.; Cardoso, R.M.; Russo, A.; Varino, F.; Mériaux, C.; et al. Effects of recent minimum temperature and water deficit increases on Pinus pinaster radial growth and wood density in Southern Portugal. Front. Plant Sci. 2016, 7, 1170. [CrossRef] [PubMed]

19. Oliveira, D.; Desprat, S.; Rodrigues, T.; Naughton, F.; Hodell, D.; Trigo, R.; Rufino, M.; Lopes, C.; Abrantes, F.; Goni, M.F.S. The complexity of millennial-scale variability in southwestern Europe during MIS 11. Quat. Res. 2016, 86, 373-387. [CrossRef]

20. Sánchez-López, G.; Hernández, A.; Pla-Rabès, S.; Trigo, R.M.; Toro, M.; Granados, I.; Sáez, A.; Masqué, P.; Pueyo, J.J.; Rubio-Inglés, M.J.; et al. Climate reconstruction for the last two millennia in central Iberia: The role of East Atlantic (EA), North Atlantic Oscillation (NAO) and their interplay over the Iberian Peninsula. Quat. Sci. Rev. 2016, 149, 135-150. [CrossRef]

21. Oliva, M.; Ruiz-Fernández, J.; Barriendos, M.; Benito, G.; Cuadrat, J.M.; Domínguez-Castro, F.; García-Ruiz, J.M.; Giralt, S.; Gómez-Ortiz, A.; Hernández, A.; et al. The Little Ice Age in Iberian mountains. Earth Sci. Rev. 2018, 177, 175-208. [CrossRef] 
22. Brázdil, R.; Pfister, C.; Wanner, H.; Von Storch, H.; Luterbacher, J. Historical climatology in Europe-The state of the art. Clim. Chang. 2005, 70, 363-430. [CrossRef]

23. Brázdil, R.; Dobrovolný, P.; Luterbacher, J.; Moberg, A.; Pfister, C.; Wheeler, D.; Zorita, E. European climate of the past 500 years: New challenges for historical climatology. Clim. Chang. 2010, 101, 7-40. [CrossRef]

24. Alcoforado, M.J.; Vaquero, J.M.; Trigo, R.M.; Taborda, J.P. Early Portuguese Meteorological Records (18th Century). Clim. Past 2012, 8, 353-371. [CrossRef]

25. Domínguez-Castro, F.; Trigo, R.M.; Vaquero, J.M. The first meteorological measurements in the Iberian Peninsula. Clim. Chang. 2013, 118, 443-455. [CrossRef]

26. Domínguez-Castro, F.; De Miguel, J.C.; Vaquero, J.M.; Gallego, M.C.; García-Herrera, R. Climatic potential of Islamic Chronicles in Iberia: Extreme droughts (AD 711-1010). Holocene 2014, 24, 370-374. [CrossRef]

27. Domínguez-Castro, F.; Vaquero, J.M.; Rodrigo, F.S.; Farrona, A.M.M.; Gallego, M.C.; García-Herrera, R.; Barriendos, M.; Sanchez-Lorenzo, A. Early Spanish meteorological records (1750-1850). Int. J. Climatol. 2014, 34, 593-603. [CrossRef]

28. Fernández-Fernández, M.I.; Gallego, M.C.; Domínguez-Castro, F.; Trigo, R.M.; García, J.A.; Vaquero, J.M.; González, J.M.; Durán, J.C. The climate in Zafra from 1750 to 1840: History and description of weather observations. Clim. Chang. 2014, 126, 107-118. [CrossRef]

29. Wheeler, D. The Gibraltar climatic record: Part 2-precipitation. Weather 2007, 62, 99-104. [CrossRef]

30. Trigo, R.M.; Pozo-Vázquez, D.; Osborn, T.J.; Castro-Díez, Y.; Gámiz-Fortis, S.; Esteban-Parra, M.J. North Atlantic Oscillation influence on precipitation, river flow and water resources in the Iberian Peninsula. Int. J. Climatol. 2004, 24, 925-944. [CrossRef]

31. Diario de Badajoz. Diario de Badajoz; Imprenta de la Capitanía General: Badajoz, Spain, 1831; pp. 137-140.

32. Fernández-Fernández, M.; Gallego, M.C.; Domínguez-Castro, F.; Trigo, R.M.; Vaquero, J.M. The climate in Zafra from 1750 to 1840: Precipitation. Clim. Chang. 2015, 129, 267-280. [CrossRef]

33. Fernández-Fernández, M.; Gallego, M.C.; Domínguez-Castro, F.; Trigo, R.M.; Vaquero, J.M. The climate in Zafra from 1750 to 1840: Temperature indexes from documentary sources. Clim. Chang. 2017, 141, 671-684. [CrossRef]

34. Hurrell, J.W. Decadal trends in the North Atlantic Oscillation: Regional temperatures and precipitation. Science 1995, 269, 676-679. [CrossRef]

35. Hurrel, J.W.; Kushnir, Y.; Ottersen, G.; Visbeck, M. The North Atlantic Oscillation: Climatic significance and environmental impact. In Geophysical Monograph Series; American Geophysical Union: Washington, DC, USA, 2003; Volume 134.

36. Zêzere, J.L.; Trigo, R.M.; Trigo, I.F. Shallow and deep Landslides induced by rainfall in the Lisbon region (Portugal): Assessment of relationships with the North Atlantic Oscillation. Nat. Hazards Earth Syst. Sci. 2005, 5, 331-344. [CrossRef]

37. Trigo, R.M.; Zêzere, J.L.; Rodrigues, M.L.; Trigo, I.F. The influence of the North Atlantic Oscillation on rainfall triggering of Landslides near Lisbon. Nat. Hazards 2005, 36, 331-354. [CrossRef]

38. Jones, P.D.; Jonsson, T.; Wheeler, D. Extension to the North Atlantic Oscillation using early instrumental pressure observations from Gibraltar and South-West Iceland. Int. J. Climatol. 1997, 17, 1433-1450. [CrossRef]

39. Gallego, M.C.; García, J.A.; Vaquero, J.M. The NAO signal in daily rainfall series over the Iberian Peninsula. Clim. Res. 2005, 29, 103-109. [CrossRef]

40. Gimeno, L.; Ribera, P.; Iglesias, R.; De la Torre, L.; García, R.; Hernández, E. Identification of empirical relationships between indices of ENSO and NAO and agricultural yields in Spain. Clim. Res. 2002, 21, 165-172. [CrossRef]

41. Trigo, R.M.; Osborn, T.J.; Corte-Real, J.M. The North Atlantic Oscillation influence on Europe: Climate impacts and associated physical mechanisms. Clim. Res. 2002, 20, 9-17. [CrossRef]

42. Luterbacher, J.; Xoplaki, E.; Dietrich, D.; Rickli, R.; Jacobeit, J.; Beck, C.; Gyalistras, D.; Schmutz, C.; Wanner, H. Reconstruction of sea level pressure fields over the Eastern North Atlantic and Europe back to 1500. Clim. Dyn. 2002, 18, 545-561. [CrossRef]

43. Trigo, R.M.; Vaquero, J.M.; Alcoforado, M.J.; Barriendos, M.; Taborda, J.; García-Herrera, R.; Luterbacher, J. Iberia in 1816, the year without a summer. Int. J. Climatol. 2009, 29, 99-115. [CrossRef] 
44. Luterbacher, J.; Pfister, C. The year without a summer. Nat. Geosci. 2015, 8, 246-248. [CrossRef]

45. Pereira, S.; Ramos, A.M.; Zêzere, J.L.; Trigo, R.M.; Vaquero, J.M. Spatial impact and triggering conditions of the exceptional hydro-geomorphological event of December 1909 in Iberia. Nat. Hazards Earth Syst. Sci. 2016, 16, 371-390. [CrossRef] 